\title{
Stock repurchases and fundamental analysis: an empirical study of the brazilian market in the period from 1994 to 2006
}

\author{
Silvania Neris Nossa ${ }^{\dagger}$ \\ Fucape Business School \\ Alexsandro Broedel Lopes ${ }^{\Omega}$ \\ University of São Paulo \\ Aridelmo Teixeira ${ }^{\ddagger}$ \\ Fucape Business School
}

\begin{abstract}
This study examines whether there is a relation between stock repurchase announcements and abnormal returns of companies classified as winners and losers. The classification as winners or losers followed the method suggested by Piotroski (2000), as adapted to the Brazilian market by Lopes \& Galdi (2007). The data were obtained from the Economática database, referring to companies listed on the São Paulo Stock Exchange (Bovespa) in the period from 1994 to 2006. The hypotheses were tested through regression with panel data. The results show no abnormal returns for both winners and losers that announced share repurchases in the entire study period, without specifying whether this was before or after issuance in 1999 of Instruction 299 by the Brazilian Securities Commission (CVM), which enhanced protection of minority shareholders in public tender offers. After segregating the study period into two subperiods, before and after the new rules, we found a negative relation with abnormal returns for losers that announced repurchases in the earlier period (1994 to 1999), while there was no statistically significant relation for winners. For the 2000-2006 period, however, there was a positive relation with abnormal returns for both winners and losers.
\end{abstract}

Keywords: Stock repurchase, winners, losers, company valuation, stock portfolios.

Corresponding Author*:

* Master's in Accounting Science from

Fucape Business School

Address: Av. Fernando Ferrari, n.1358,

Goiabeiras - Vitória - ES - Brazil

CEP 29.075-505.

E-mail: silvanianossa@uol.com.br Telephone: (27) 40094444 Fax: (27) 40094422

\author{
${ }^{\Omega} \mathrm{Ph}$.D. in Accounting and Finance from \\ Manchester Business School \\ Professor of the University of São Paulo \\ Address: Av. Prof. Luciano Gualberto \\ 908 - FEA3 - São Paulo - SP - Brazil \\ CEP 05508-900. \\ E-mail: broedel@usp.br \\ Telephone: (11) 30915820 FAX: (11) \\ 30915822
}

\footnotetext{
${ }^{¥}$ Ph.D. in Control and Accounting from the University of São Paulo. Professor at Fucape Business School Address: Av. Fernando Ferrari, nº.1358, Goiabeiras, Vitória - ES - Brazil CEP 29.075-505.

E-mail: aridelmo@fucape.br Telephone: (27) 40094444 Fax: (27) 40094422
} 


\section{INTRODUCTION}

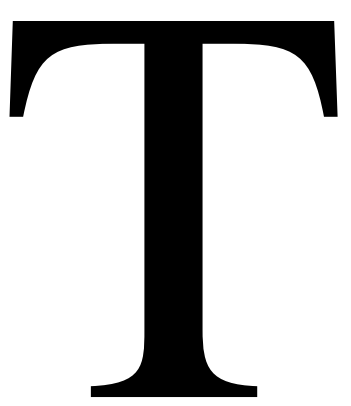

he aim of this study is to determine whether there is a relation between announcement of share repurchases by companies classified as winners or losers and abnormal returns in the year of the offer, among companies listed on the São Paulo Stock Exchange (Bovespa), based on data for the period from 1994 to 2006. The firms' classification as winners or losers was based on their results two years before the repurchase announcement. The empirical results are partly contrary to the findings of other authors in the Brazilian and international literature.

Shareholders obviously seek to invest in companies that provide abnormal positive returns, meaning returns that outperform the market as a whole. Piotroski (2000) stressed that choosing firms likely to attain positive abnormal returns in the future (winners) by means of financial indicators is a task that requires further study.

The present study is an outgrowth of the findings presented by Piotroski (2000), Gabrielli \& Saito (2004) and Lopes \& Galdi (2007).

Lopes \& Galdi (2007) adapted and tested the proposition of Piotroski (2000) in the Brazilian market and observed that it is possible to obtain abnormal positive returns by analyzing nine accounting indicators to classify firms as winners or losers, according to the expected future return.

Gabrielli \& Saito (2004), also studying the Brazilian market, found that companies that announced share repurchases in the period from 1994 to 1999 produced negative abnormal returns. They explained this because of the issuance of CVM Instruction 299 in 1999, which among other measures enhanced the protection of minority shareholders in public tender offers. They also found that the variation in the concentration of winners and losers could be an explanation for the variation in the sign of abnormal returns.

In light of the above, this article investigates the question: Is there a relation between share repurchase announcements and abnormal returns of firms classified as winners and losers in the Brazilian market?

Various explanatory variables of abnormal returns have been studied, such as price-to-book, size, liquidity and leverage (debt/assets) (Fama \& French, 1996; Ho, Liu 
\& Ramanan, 1997; Ikembery, Lakonishok \& Vermaellen, 2000; Dittmar, 2000;

D’Mello \& Shroff, 2000; Piotroski, 2000; and Lopes \& Galdi, 2007).

Here I use panel regression with fixed effects to study the relation between abnormal returns, as the dependent variable, and the following explanatory variables: classification as winner or loser; firms that announce share repurchase; and the temporal impact found by Gabrielli \& Saito (2004). I also employ some of the main control variables indicated in the literature, such as price-to-book (Fama \& French, 1996), liquidity, size and indebtedness (Piotroski, 2000 and Lopes \& Galdi, 2007).

This study helps give a better empirical view of the relationship of share repurchase programs and fundamental analysis with abnormal returns, by providing new information about the Brazilian market.

\section{REVIEW OF THE LITERATURE}

\subsection{Portfolios chosen by fundamental analysis}

The relevance of accounting for the capital market has been examined by Ball \& Brown (1968), Baruch \& Thiagarajan (1993), Fama \& French (1996), Abarbanell \& Bushee (1997), Abarbanell \& Bushee (1998), Ali \& Hwang (2000), Bird, Gerlach \& Hall (2001), Piotroski (2000; 2005), Mohanram (2005), and Lopes \& Galdi (2007), among other researchers who have studied the relation of accounting indicators and stock returns, to give investors a better chance to obtain good returns.

Piotroski (2000) used financial information on American firms in the period from 1976 to 1996 to calculate an "F_Score" to classify firms as winners or losers and suggested that one of the strategies investors could use to find a balance between risk and return would be to observe financial indicators, distribution of dividends, accruals, stock issues and repurchase programs.

Lopes \& Galdi (2006) and Lopes \& Galdi (2007) suggested some adaptations to the F_Score proposed by Piotroski (2000), to adapt it to the peculiarities of the Brazilian market, and also proposed the use of another score, called the R_Score, based on some quasi-continuous indicators.

In applying the F_Score and R_Score to the Brazilian market, Lopes \& Galdi (2007) corroborated the results found by Piotroski (2000) in the United States, finding a 
positive relation between a portfolio of winners and abnormal returns, especially in the second year after building the portfolio.

Both Piotroski (2000) and Lopes \& Galdi (2007) observed an opportunity to use financial information as a mechanism to reduce information asymmetry. However, Lopes \& Galdi (2007) stressed that the economic reality represented by financial ratios appears to be incorporated more slowly in the price of Brazilian shares than in American ones.

\subsection{Price-to-book, size, liquidity and leverage}

I use the variables price-to-book, firm size, liquidity and leverage (debt/assets) as control variables. These have been tested in previous articles to explain abnormal returns (Fama \& French, 1996; Ho, Liu \& Ramanan, 1997; Ikembery, Lakonishok \& Vermaellen, 2000; Dittmar, 2000; D’Mello \& Shroff, 2000; Piotroski, 2000; and Lopes \& Galdi, 2007).

Size was used as a control variable by D’Mello \& Shroff (2000), Dittmar (2000) and Ho, Liu \& Ramanan (1997). In the Brazilian market, Lopes \& Galdi (2007) concluded that if an investor bought shares of winners and sold them in one year or two years, he would obtain a positive abnormal return of $8.3 \%$ or $11.5 \%$, respectively.

If this same investor invested only in winning small and medium sized firms, the abnormal return would rise to $34.5 \%$ if selling after one year and $98.2 \%$ if waiting two years.

This result is different than that of Piotroski (2000), according to which the efficiency of a portfolio of winners is independent of the firms' size.

According to Bezerra \& Lopes (2004), in the Brazilian market preferred shares have the highest liquidity. On the matter of liquidity, Lopes \& Galdi (2007) found evidence that the returns of winners and losers are different for firms with low liquidity in the Brazilian market.

The leverage indicator (debt/assets) was studied by Piotroski (2000), who observed that a strategy of separating winners from losers works independently of the level of firms' indebtedness. In the Brazilian market, Lopes \& Galdi (2007) found evidence that a strategy of separating winners from losers is more efficient for firms with higher leverage. 


\subsection{Repurchase of shares and fundamental analysis}

The repurchase by firms of their own shares is defined by Ross, Westerfield \& Jaffe (2002), Grullon \& Michaelly (2002, p. 1675), Gabrielli \& Saito (2004) and Piotroski (2000) as a strategy that can have several aims: to reduce agency cost, to take the place of paying dividends, to manage capital structure and to signal to the market that a firm's shares are undervalued.

The fact that some firms signal events that generate positive abnormal returns and others signal events that generate negative abnormal returns is based on agency conflict, according to Jensen \& Meckling (1976) and Akerlof (1970). With respect to signaling theory, Spence (1973) argued that by adopting certain practices, firms can send neutral, positive or negative signals to interested parties.

Searching for an explanation, by empirical testing, for the fact that firms repurchase their own shares, Dittmar (2000) observed that firms do this to distribute cash, manage their leverage and as part of employee and management stock option plans.

Bens \& Wong (2007) corroborated the result found by Dittmar (2000), referring to management of earnings per share to increase the value of stock options. Jensen \& Meckling (1976, p. 308) argued that agents with access to information about the firm can use it in their own personal interests, in detriment to those of the shareholders.

In analyzing stock repurchase based on signaling theory, Dielman, Tinothy \& Wright (1980), Dann (1981), Vermaelen (1981), Lakonishok \& Vermaelen (1990), Liano, Huang \& Manakyan(1990), Comment \& Jarrell (1991), Ikenberry, Lakonishok \& Vernaelen (2000), D’Mello \& Shroff (2000), Dittmar (2000), Grullon \& Michaelly (2002), Lie (2005), and Bens \& Wong (2007) all observed positive returns for companies that announced stock buybacks.

In contrast, the results of the study by Stephens \& Wisbash (1998) indicated that share repurchase announcements are inversely related to returns. In Brazil, Moreira (2000) and Gordon (2002) concluded that repurchasing shares signals positive abnormal returns. Gabrielli \& Saito (2004), on the other hand, concluded that the abnormal returns were negative in the period from 1994 to 2002, for companies that announced stock repurchases. 
The legal support for repurchase of shares in Brazil is provided by Law 6385 of 1976 (Brasil, 1976), which covers the capital market and created the Brazilian Securities Commission (CVM). According to the basic law on corporations, Law 6404/76 (Art. $30, \S 2)$, the acquisition by a listed company of its own shares "shall obey, under penalty of nullity, the rules established by the Comissão de Valores Mobiliários, which may subject such acquisition to its previous authorization in each case."

Although the focus of this study is on the effects of CVM Instruction 299/1999, highlighted by Gabrielli \& Saito (2004) as a mechanism to protect minority shareholders in relation to share repurchases, I also analyzed other instructions issued by the CVM up through 2007.

I did not find any changes that can modify the rules or interpretation of CVM Instruction 299/1999 so as to undermine the theoretical support presented by Gabrielli $\&$ Saito (2004) about its importance as a mechanism to protect the interests of minority shareholders.

Article 3 of CVM Instruction 345/2000 amended Art. 12, VIII, of CVM Instruction 299/1999, establishing that if holders of more than one-third of the free float shares express their intention of participating in the repurchase auction, the company must: "(i) withdraw the offer; (ii) proceed with the acquisition in proportion to the number of shares owned by shareholders accepting the offer, up to the limit of one-third of the shares in circulation; or (iii) initiate a new public tender offer procedure."

Gabrielli \& Saito (2004) concluded that before the application of CVM Instruction 299/1999, share repurchases led to accumulated abnormal returns of negative $10 \%$, while afterward this figure was positive $4 \%$. In other words, there is evidence that this instruction benefited minority shareholders (Gabrielli \& Saito, 2004).

The result of the study by Gabrielli \& Saito (2004) indicates that the new rules provided by CVM Instruction 299/1999 were a factor to explain the variation in abnormal returns of companies that announced share repurchases in the period analyzed. However, besides this change in the regulatory framework, there are other factors that can explain the abnormal returns after share repurchase offers.

As explained by Fama \& French (1996), Piotroski (2000) and Lopes \& Galdi (2007), among these factors are price-to-book, liquidity, size, leverage and the classification as winner or loser. 
The strategy of building a portfolio containing the shares of companies satisfying certain financial indicators and that repurchase shares is aimed at increasing the probability of obtaining positive abnormal returns. In this respect, Ho, Liu \& Ramanan (1997), besides stressing the importance of accounting numbers to investors, observed that share repurchase is positively related to earnings per share and growth of sales between the period before and after the announcement.

D'Mello \& Shroff (2000, p. 2422) separated firms by their stock price as undervalued or overvalued, by applying the model of Ohlson (1995) and controlling for size. D'Mello \& Shroff (2000) concluded that small firms that announce share repurchases attain better returns than large firms doing the same.

Lie (2005) studied companies that announced share repurchases and analyzed their earnings disclosures, concluding that the market reacts more favorably to disclosure of earnings and operational performance in the case of companies that carry out the repurchase in the same year as announced than to firms that do not do so within the same year.

\section{METHODOLOGY}

This paper is in the positive accounting research tradition, based on analysis of empirical data about companies listed on the São Paulo Stock Exchange (Bovespa) from 1994 to 2006. It is an extension of the observations of Lopes \& Galdi (2007) and Gabrielli \& Saito (2004) regarding the Brazilian market. Lopes \& Galdi (2007) stated that by using accounting information it is possible to separate winning from losing companies according to the expectation of abnormal stock returns. In turn, Gabrielli \& Saito (2004) found that Brazilian firms that repurchased shares in the period before CVM Instruction 299/1999 obtained a negative average abnormal return, while firms that did so after the change in rules attained a positive average abnormal return.

Based on these findings, one would expect there to be a relation between abnormal returns and the announcement of share repurchases by winners and losers. The null hypothesis tested here is thus: $\mathrm{H}_{0}$ : There is no relation between the announcement of stock repurchase by winners or losers and abnormal returns.

I tested this null hypothesis considering the periods before and after the publication of CVM Instruction 299/1999, to verify whether this variable had any influence on the abnormal returns beforehand and afterward.The method for classifying 
winners and losers here is based on Lopes \& Galdi (2007), who adapted and tested the method proposed by Piotroski (2000) for the Brazilian market, concluding that financial information in Brazil can help investors to value companies. The impact of fundamental analysis can be verified by the differences in abnormal returns of companies classified as winners and losers according to accounting indicators. This study is based on the fourth-quarter financial disclosures of firms listed on the Bovespa, obtained from the Economática database. I used these figures to calculate financial indicators for profitability, capital structure and operational efficiency (Table 1), and then employed these to calculate the F_Score, to classify firms as winners or losers according to the table.

Table 1: Indicators for calculating the F_Score

\begin{tabular}{|c|c|c|c|}
\hline \multirow{8}{*}{ 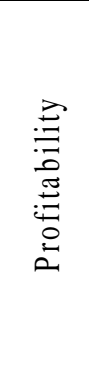 } & \multirow{2}{*}{ ROA } & \multirow{2}{*}{$L_{i t-2}$ / AtivoTotal $_{t-3}$} & ROA $>0$ (1) \\
\hline & & & $\mathrm{ROA}<0(0)$ \\
\hline & \multirow{2}{*}{ CF } & \multirow[b]{2}{*}{$\left(\right.$ Checx $_{i t-2}$ Check $\left._{i t-3}\right) /$ AtivoTotal $_{t-3}$} & $\mathrm{CF}>0(1)$ \\
\hline & & & $\mathrm{CF}<0(0)$ \\
\hline & \multirow{2}{*}{$\triangle \mathrm{ROA}$} & \multirow{2}{*}{$R O A_{i t-2}-R O A_{i t-3}$} & $\triangle \mathrm{ROA}>0(1)$ \\
\hline & & & $\triangle \mathrm{ROA}$ \\
\hline & \multirow{2}{*}{ ACCRUAL } & \multirow{2}{*}{$\left(L L_{i t-2}-\left(C X E C X_{i t-2}-C X E C X_{i t-3}\right)\right) /$ AtivoTotal $_{t-3}$} & $\mathrm{CF}>\mathrm{RC}$ \\
\hline & & & $\mathrm{CF}<$ \\
\hline \multirow{6}{*}{ 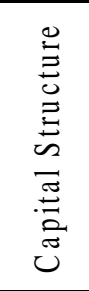 } & \multirow{2}{*}{$\triangle$ LIQUID } & \multirow{2}{*}{$\left(\right.$ Ativo Circ $_{i t-2} /$ P.Circ $\left._{i t-2}\right)-\left(\right.$ Ativo Circ $_{i t-3} /$ P.Circ $\left._{i t-3}\right)$} & $\Delta$ LIQUID $>0(1)$ \\
\hline & & & $\Delta$ LIQUID $<0(0)$ \\
\hline & \multirow{2}{*}{$\triangle \mathrm{LEVER}$} & \multirow{2}{*}{$\left(\left(P . \operatorname{Cir}_{G_{t-2}}+P E L P_{t-2}\right) / \operatorname{Ativ}_{q_{-2}}\right)-\left(\left(P . \operatorname{Cir}_{q_{t-3}}+P E L P_{t-3}\right) /\right.$ Ativg $\left._{-3}\right)$} & $\Delta$ LEVER $<0(1)$ \\
\hline & & & $\Delta$ LEVER $>0(0)$ \\
\hline & \multirow[t]{2}{*}{ EQ_OFFER } & \multirow{2}{*}{$\begin{array}{l}\text { If the company issued equity in the last year before forming the portfolio, then it } \\
\text { receives a value of zero (o), and one (1) if it did not issue equity. }\end{array}$} & EQ_OFFER = $0(1)$ \\
\hline & & & EQ_OFFER > $0(0)$ \\
\hline \multirow{4}{*}{ 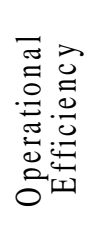 } & \multirow{2}{*}{$\triangle \mathrm{MARGIN}$} & \multirow{2}{*}{$\left(\right.$ LucBrutit $\left./ \operatorname{Re} c_{i t-2}\right)-\left(\right.$ LucBrut $\left._{i t-3} / \operatorname{Re} c_{i t-3}\right)$} & $\Delta$ MARGIN >0 (1) \\
\hline & & & $\Delta$ MARGIN $<0(0)$ \\
\hline & \multirow{2}{*}{$\Delta$ TURN } & \multirow{2}{*}{$\left(\operatorname{Re} c_{i t-2} /\right.$ Ativo $\left._{i t-2}\right)-\left(\operatorname{Re} c_{i t-3} /\right.$ Ativo $\left._{i t-3}\right)$} & $\Delta \mathrm{TURN}>0(1)$ \\
\hline & & & $\Delta \mathrm{TURN}<0(0)$ \\
\hline
\end{tabular}

Source: Adapted from Piotroski (2000) and Lopes \& Galdi (2007).

Where:

$$
\begin{aligned}
& \text { CCEQ = cash and cash equivalents } \\
& \text { CASS = current assets } \\
& \text { CLIAB = current liabilities } \\
& \text { LTLIAB = long-term liabilities } \\
& \text { GRINC = gross income } \\
& \text { REV = sales revenues } \\
& \mathrm{NI}_{\text {it }}=\text { net income of company } \mathrm{i} \text { in period } 1 \text {; }
\end{aligned}
$$

CHART 1: VARIABLES FROM TABLE 1

Source: Adapted from Piotroski (2000) and Lopes \& Galdi (2007). 
In formulating the financial indicators, I followed the proposal of Lopes \& Galdi (2007), principally in relation to cash and cash equivalent. Thus, ROA, $\triangle$ ROA, CTA (cash and cash equivalents to total assets) and ACCRUAL indicate the firms' profitability; $\triangle$ LIQUID, $\triangle$ LEVER and EQ_OFFER indicate their capital structure; and $\triangle$ MARGIN and $\triangle T U R N$ (change in asset turnover ratio) represent their operational efficiency. Profitability indicators - I attributed a score of one to firms with ROA and $\triangle$ ROA greater than zero, and zero to those with ROA and $\triangle \mathrm{ROA}$ less than zero. I further attributed a score of one to firms with $\mathrm{CF}$ greater than ROA, and zero to firms with CF less than ROA.

Capital structure indicators - I assigned a score of one to firms with variation in liquidity greater than zero, and zero to firms with variation in liquidity less than zero. I also assigned a value of one to firms with variation in leverage less than zero, and zero to firms where this variation was greater than zero. Finally, I attributed a score of one to firms that issued shares (equity offer) in the year before formulation of the portfolio and zero to firms that did not issue shares. Operational efficiency indicators - I attributed a score of one to firms presenting a change in margin indicator greater than zero, and zero to firms with a variation in margin less than zero. Likewise, I assigned a score of zero to firms with variation in asset turnover greater than zero and zero to firms where this variation was less than zero. Based on this scheme, the nearer to nine the total score is, the more winning the firm is.

After formulating the scheme for calculating the F_Scores, I examined the Economática database for firms that announced a share repurchase in the study period. There were 1,268 such announcements, of which 281 announcements (at least one announcement per company in each year) corresponded to companies with financial information and the other variables available. These formed the panel for testing.

The use of a portfolio chosen two years before the repurchase announcement was based on the results found by Lopes \& Galdi (2007), according to which the strategy of separating firms into winners and losers with respect to abnormal returns particularly occurs two years after choosing the portfolio.From the F_Score of the companies that announced share repurchases, I classified those in the top $20 \%$ as winners and those in the lowest $20 \%$ as losers, following the classification parameters proposed by Piotroski (2000) and Lopes \& Galdi (2007). Also following Piotroski (2000) and Lopes \& Galdi (2007), I excluded firms with negative equity. I also 
excluded outliers from the winners and losers (the highest and lowest $2.5 \%$ of the indicators) in calculating the F_Scores, according to the method used by Lopes \& Galdi (2007).I then used regression analysis of panel data. According to Gujarati (2002, p. 636):

There are other names for panel data, such as pooled data (pooling of time and cross-sectional observations), combination of time series and crosssectional data, longitudinal data (a study over time of a variable or group of subjects), event history analysis, (e.g., studying the movement over time of subjects through successive states or conditions), cohort analysis (e.g., following the career paths of 1965 graduates of a business school).

According to Gujarati (2006, p. 637), the use of regression analysis with panel data allows representing in a single equation abnormal returns and the various combinations of winners and losers that did and did not announce share repurchases. It can also take into consideration the temporal impact found by Gabrielli \& Saito (2004) and also allow the insertion of control variables indicated in the literature, such as priceto-book (Fama \& French, 1996), liquidity, size and leverage (Piotroski, 2000 and Lopes \& Galdi, 2007). Abnormal return $\left(\mathrm{AR}_{\mathrm{it}}\right)$, according to Sarlo Neto (2004), is the difference between the rate of return of an asset (Equation 1) and its expected return (Equation 2).

$$
R_{i t}=\left(p_{i t}-p_{i t-1}\right) \div p_{i t-1}
$$

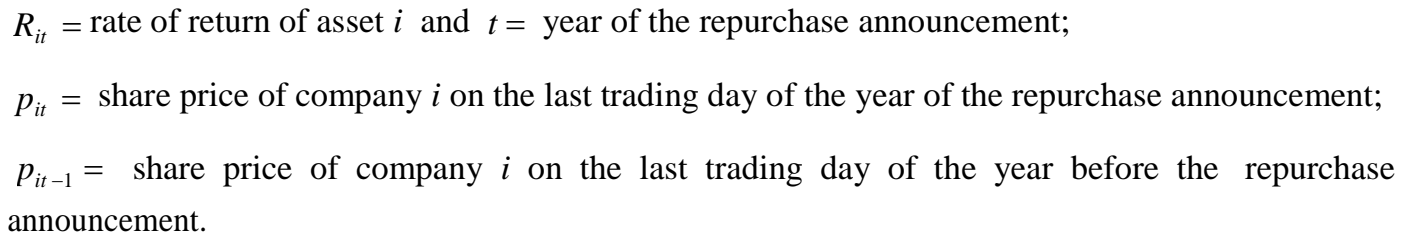

The calculation of the expected return (Equation 2) followed the proposal of Mellagi Filho \& Ishikawa (2000). In the Brazilian market, the interest rate paid on passbook savings accounts is commonly used as a proxy for the risk-free rate of return (Sant'Anna, 2004). The model to determine the price of the assets (capital asset pricing model - ACPM) was calculated from the Bovespa Index (Ibovespa) for the last trading day of the year of the repurchase announcement for each company. Both the annual Ibovespa and the annual rate paid on savings accounts were obtained from the Ipeadata site (BRASIL, 2007). Each firm's beta was obtained from the Economática database (Equation 2). 


$$
E\left(R_{i t}\right)=R_{F}+\beta_{i t}\left[E\left(R_{M}\right)-R_{F}\right]
$$

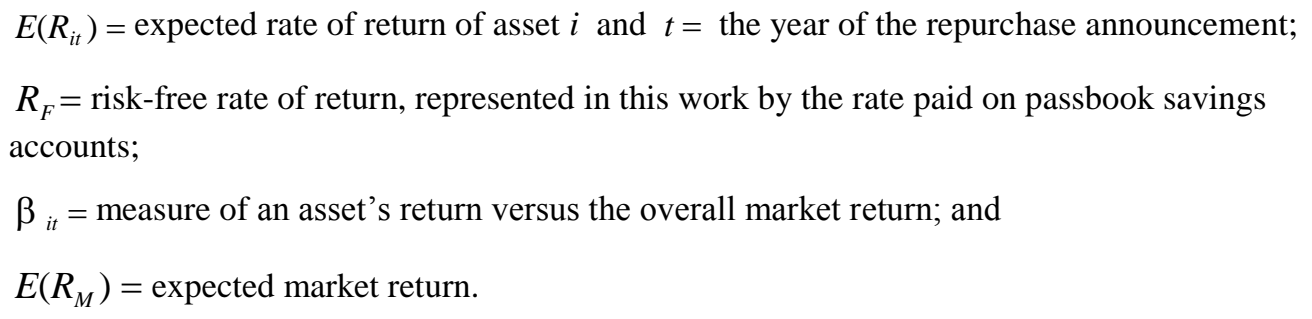

\section{CHART 3: VARIABLES OF EQUATION 2}

Source: Mellagi Filho e Ishikawa (2000)

Again, the highest and lowest $2.5 \%$ were excluded from the abnormal returns, as well as from the control variables.Equation 3 is the panel regression equation, without considering the period before and after issuance of CVM Instruction 299/1999, and Equation 4 contains a dummy to represent the temporal effect observed by Gabrielli \& Saito (2004).The control variables used here were included to reduce the stochastic error, already foreseen in Equation 2. I adopted this procedure based on a review of the literature and chose variables already used in relation to abnormal return by Brown, Lo \& Lys (1999), Fama \& French (1996), Piotroski (2000) and Lopes \& Galdi (2007).

$$
\begin{aligned}
& R A_{i t}=\beta_{0}+\beta_{1} \delta_{\text {Winner }}{ }_{i t-2}+\beta_{2 .} \delta_{\text {Loser }}{ }_{i t-2}+\beta_{3 .} \text { PTB }{ }_{i t} \\
& +\beta_{4 .} \text { size }{ }_{i t}+\beta_{5 .} \text { Liq it }+\beta_{6 .} \text { Debts / assets }{ }_{i t}+\xi_{i t}
\end{aligned}
$$

\footnotetext{
$\left(R A_{i t}\right)=$ abnormal return of asset $i$ and $t=$ year of the repurchase announcement

$\beta_{0}=$ intercept

$\delta_{\text {Winner it }-2}=$ company that announced a share repurchase and that was classified two years beforehand as a winner. It is a dummy variable that assumes the value of one for winners that announced a repurchase and zero for companies that are not winners.
}

$\delta_{\text {Loserit-2 }}=$ company that announced a share repurchase and that was classified two years beforehand as a loser. It is a dummy variable that assumes the value of one for losers that announced a repurchase and zero for other companies.

Debts $/$ assets $_{i t}=($ current + long-term liabilities $) /$ total assets

size $=$ Ln of assets

$L i q_{i t}=$ current liquidity

$\xi_{i t}=$ stochastic error terms of the panel regression

CHART 4: VARIABLES OF EQUATION 3

Source: elaborate by the authors 
In calculating the price-to-book ratio for the period before the announcement, I followed the proposal of Brown, Lo \& Lys (1999) to eliminate the scale effect.

Equation 5 includes in the model the time differentiation found by Gabrielli \& Saito (2004), according to which in the period before CVM Instruction 299/1999, companies that announced share repurchases were sending negative signals to the market while afterward repurchase announcements started to be a positive signal.

The periods before and after CVM Instruction 299/1999 are represented by a dummy, which is zero for the preceding period (1994-1999) and one for the succeeding one (2000-2006), in each case multiplied by a winner/loser dummy variable.

$$
\begin{aligned}
& R A_{i t}=\beta_{0}+\beta_{1 .} \delta_{94-99} \cdot \delta_{\text {Winner it }-2}+\beta_{2 .} \delta_{94-99} \cdot \delta_{\text {Loser } i t-2} \\
& +\beta_{3} . \delta_{00-06} \cdot \delta_{\text {Winner it }-2}+\beta_{4 .} \delta_{00-06} \cdot \delta_{\text {Loser }_{i t-2}}+\beta_{5 .} \text { PTB }{ }_{i t} \\
& +\beta_{6} \text { size }_{i t}+\beta_{7 .} \text { Liq }_{i t}+\beta_{8} \text { Debts / } \text { assets }_{i t}+\xi_{i t}
\end{aligned}
$$

$\delta_{94-99} \cdot \delta_{\text {Winnerit-2 }}={ }_{\text {A dummy that is zero for the period after CVM Instruction 299/1999 and }}$ one beforehand, multiplied by another dummy variable that is one for companies listed on the Bovespa that announced a share repurchase and were classified as winners two years before the announcement, or zero if not classified as winners.

$\delta_{94-99} \cdot \delta_{\text {Winnerit-2 }}=$ A dummy that is zero for the period after CVM Instruction 299/1999 and one beforehand, multiplied by another dummy that is one for companies listed on the Bovespa that announced a share repurchase and were classified as losers two years before the announcement, or zero if not classified as losers.

$\delta_{00-06} \cdot \delta_{\text {Winnerit-2 }}={ }_{\text {A dummy that is zero for the period before CVM Instruction 299/1999 and }}$ one afterward, multiplied by another dummy that is one for companies listed on the Bovespa that announced a share repurchase and were classified as winners before the announcement, or zero if not classified as winners.

$\delta_{00-06} \cdot \delta_{\text {Loserit-2 }}=$ A dummy that is zero for the period before CVM Instruction 299/1999 and one afterward, multiplied by another dummy that is one for companies listed on the Bovespa that announced a share repurchase and were classified as losers two years before the announcement, or zero if not classified as losers.

\section{CHART 5: VARIABLES OF EQUATION 4}

Source: elaborate by the authors

To decide between panel data regression analysis with fixed or random effects, I used the Hausman test (Tables 2 and 3), which according to Greene (1997) and Wooldridge (2006) tests whether the coefficients of the panel with fixed effects and that with random effects are systematically different. 
Another test conducted to make the results more robust is the use of leverage as a control variable. Both Piotroski (2000) and Lopes \& Galdi (2007) employed the debtto-assets ratio as the leverage indicator.

In this study I also used the debt-to-equity ratio and found no significant difference in the Brazilian market between the outcomes, as shown in Appendix C. Therefore, I only consider debt/assets as the leverage variable in the results.

Wooldridge (2006, p. 445) states that using panel regression with "fixed effects is the same as allowing a different intercept for each observation, and we can estimated these intercepts by including dummy variables...".

Based on this, I carried out a pooled regression analysis to check whether the results found by panel regression with fixed effects were consistent with those found by pooled regression (Appendix B), although the robust tool is not used in pooled regressions.

The results are constructed from panel regression analysis with fixed effects and the robustness tool, which according to Greene (1997, p. 635) can correct possible problems due to the existence of heteroskedasticity. Appendix

A presents the descriptive statistics of the variables used, in general and separately for firms classified as winners and losers.

\section{ANALYSIS OF THE RESULTS}

This section presents the results and analysis of the panel regression, to answer the research question: Is there a relation between share repurchase announcements and abnormal returns by firms classified either as winners or losers?

Table 2 provides indications, by means of the Hausman test, that there is no systematic difference in the coefficients when comparing the results of the panel regression with fixed effects against that with random effects. Therefore, I assumed panel regression with fixed effects, both for Equation 3 and Equation 4.

$$
\begin{aligned}
& R A_{i t}=\beta_{0}+\beta_{1} \delta_{\text {Winner }}{ }_{i t-2}+\beta_{2} \delta_{\text {Loser }}{ }_{i t-2}+\beta_{3} \text { PTB }{ }_{\text {it }}
\end{aligned}
$$

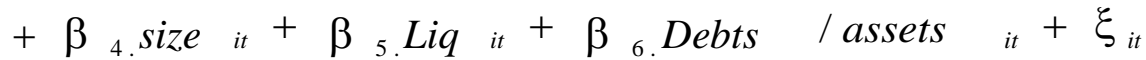


Table 2: Result of the panel regression analysis

\begin{tabular}{c|c|c|c|c|c|c|c|c}
\hline$\beta_{0}$ & $\beta_{1}$ & $\beta_{2}$ & $\beta_{3}$ & $\beta_{4}$ & $\beta_{5}$ & $\beta_{6}$ & & \multirow{2}{*}{ Hausman } \\
\hline-0.90 & 0.18 & -0.04 & -0.12 & 0.03 & 0.12 & 1.00 & \multirow{2}{*}{0.00} & \multirow{2}{*}{0.00} \\
\hline$(-0.66)$ & $(1.54)$ & $(-0.33)$ & $(-11.91)^{*}$ & $(0.30)$ & $(1.61)$ & $(4.97)^{*}$ & & \\
\hline
\end{tabular}

Note: * Significant at $1 \%(t$-statistic in parentheses

Source: elaborate by the authors

It can be seen that both winners $\left(B_{1}\right)$ and losers $\left(B_{2}\right)$ have a relation with abnormal returns in the period from 1994 to 2006 (Table 2, Equation 3). This means that investors do not respond in statistically significant form to stock repurchase announcements, for either winners or losers. Although the relation of the winners and losers is not significant, the sign of the winners' coefficient ( $\mathrm{p}$-value $=0.13$ ) is positive, while the sign of the losers' coefficient ( $p$-value $=0.74$ ) is negative.

$$
\begin{aligned}
& R A_{i t}=\beta_{0}+\beta_{1 .} \delta_{94-99} . \delta_{\text {Winner }}{ }_{i t-2}+\beta_{2 .} \delta_{94-99} . \delta_{\text {Loser }}{ }_{i t-2} \\
& +\beta_{3} . \delta_{00-06} . \delta_{\text {Winner }}{ }_{i t-2}+\beta_{4 .} \delta_{00-06} . \delta_{\text {Loser it }-2}+\beta_{5 . P T B} \text { it } \\
& +\beta_{6} . \text { size }{ }_{i t}+\beta_{7} . \text { Liq }_{i t}+\beta_{8} \text {.Debts } / \text { assets }{ }_{i t}+\xi_{i t}
\end{aligned}
$$

In the panel analysis (Equation 4), I separately analyzed the winners and losers that announced share repurchases in the two sub-periods (1994-1999 and 2000-2006), by multiplying the time dummy by the dummy variables $D$. Winner or D.Loser.

Table 3 shows there was of a statistically significant (at 1\%) inverse relationship between abnormal returns and announcements by losers of share buybacks in the earlier period (1994-1999). In other words, investors reacted negatively, by means of the stock price, when firms classified as losers announced share repurchases in that period.

The same analysis for winners in that period did not reveal any significant relation, although the sign of the coefficient of the firms classified as winners was positive.

Table 3: Result of the panel regression analysis

\begin{tabular}{c|c|c|c|c|c|c|c|c|c|c}
\hline$\beta_{0}$ & $\beta_{1}$ & $\beta_{2}$ & $\beta_{3}$ & $\beta_{4}$ & $\beta_{5}$ & $\beta_{6}$ & $\beta_{7}$ & $\beta_{8}$ & $F$ & Hausman \\
\hline-0.91 & 0.14 & -0.63 & 0.22 & 0.24 & -0.12 & 0.03 & 0.12 & 0.99 & \multirow{2}{*}{0.00} & \multirow{2}{*}{0.00} \\
\hline$(-0.66)$ & $(0.63)$ & $(-4.30)^{*}$ & $(1.94)^{* * *}$ & $(1.98)^{* * *}$ & $(-12.01)^{*}$ & $(0.31)$ & $(1.60)$ & $(4.99)^{*}$ & & \\
\hline
\end{tabular}

Note: $*, * *, * * *$ mean significance at $1 \%, 5 \%$ and $10 \%$ respectively ( $t$-statistic in parentheses)

Source: elaborate by the authors

The analysis of the relation between abnormal returns and share repurchase announcements in the later period (2000-2006) revealed a positive and significant relation for both winners and losers (Table 3). 
The signs of beta 1 , beta 2 , beta 3 and beta, (Table 3 ) indicate a change in investors' reaction to share repurchase announcements by winners and losers before and after 2000. This corroborates the results found by Gabrielli \& Saito (2004) as well as those of Lopes \& Galdi (2007), that accounting information can help investors to obtain better returns in the Brazilian stock market,

Some explanations can be suggested as to why there was a positive relation between abnormal returns and share buyback announcements for both winners and losers in the period from 2000 to 2006.

- The announcement of the intention to repurchase shares is a positive sign to the market, which dominates "poor" fundamentals in the case of losers;

- The period was characterized by a substantial appreciation of the market in general and this can be a "poor" adjustment to risk; and

- To calculate expected return, it may be better to use an arbitrage pricing theory (APT) market model instead of the CAPM;

\section{CONCLUSION}

In this study I analyzed the effect on abnormal returns of share repurchase announcements by companies listed on the Bovespa in the period from 1994 to 2006. In the first analysis, without separating this interval into sub-periods before and after issuance of CVM Instruction 299/1999, the results indicate there was no relationship between these announcements and abnormal returns for either companies classified as winners or losers.

However, the analysis of these two sub-periods separately for winners and losers showed that in the period from 1994 to 1999, the market reacted negatively to stock repurchase announcements by losers, while for winners there was no significant effect on abnormal returns.

In contrast, in the period from 2000 to 2006, announcements by both winners and losers had a positive effect on abnormal returns.

Therefore, the null hypothesis that "there is no relation between the announcement of stock repurchase by winners or losers and abnormal returns" was rejected. 
The expected result was that share repurchase announcements by winners should have a positive effect on abnormal returns. This was confirmed, although for the period from 1994 to 1999 it was not statistically significant.

The expected relation for losers and abnormal returns was negative. This was empirically confirmed for the period from 1994 to 1999 but was the opposite in the period from 2000 to 2006.

Among the possible explanations for the fact that there was a positive relation with abnormal returns for both winners and losers in the period from 2000 to 2006, are: (i) the mere announcement of a share repurchase program is a strong enough positive signal to dominate the signals sent by the financial indicators used to classify firms as winners or losers; (ii) this period was mainly marked by a strong bull market, which impaired the analysis; and/or (iii) another method than the CAPM should be used to calculate expected returns, such as a market model based on APT.

Although both winners and losers presented a positive relation with abnormal returns, nothing can be said about firms classified as intermediate between these categories, since this study did not consider them.

Based on the above, the results of this study corroborate those of Gabrielli \& Saito (2004), that there are indications of a shift in the climate for share repurchases before and after 2000 in the Brazilian market, due to the issuance of CVM Instruction 299/1999. The results here also corroborate the findings of Lopes \& Galdi (2007), that financial information can help investors obtain better returns.

Some interesting topics for future research can be mentioned:

- After separation of winners by financial indicators, analysis of dividend distribution, accruals, stock issues and corporate governance, among other factors pointed out in the literature that can provide positive abnormal returns;

- Application of the Ohlson model (1995) to examine the relationship between share repurchase announcements and abnormal returns of firms with greater upside (winners);

- Verification for the Brazilian market of the possible causes of share repurchases - in this respect, studies in the international literature have already 
tested some possibilities, such as cash (available and expected) and earnings management.

\section{REFERENCES}

ABARBANELL, Jeffrey S.; BUSHEE, Brian J. Abnormal return to a fundamental analysis strategy. The Accounting Review. v. 73, n. 1, pp. 19-45, 1998.

Fundamental analysis, future earnings, and stock prices. Journal of Accounting Research, v. 35, n. 1, pp. 1-24, 1997.

AKERLOF, George A. The market for "lemons": Quality uncertainty and the market mechanism. The Quarterly Journal of Economics, v. 84, n. 3, pp. 488-500, Aug. 1970.

ALI, Ashiq; HWANG, Lee-Seok. Country-specific factors related to financial reporting and the value relevance of accounting data. Journal of Accounting Research. v. 31, n. 1, pp. 1-21, 2000.

BALL, Ray; BROWN, Philip. An empirical evaluation of accounting income numbers. Journal of Accounting Research, v. 6, n 2, pp. 159-178, 1968.

BARUCH, Lev; THIAGARAJAN, S. Ramu. Fundamental information analysis. Journal of Accounting Research, v. 31, n. 2. pp. 190-215, 1993.

BENS, Daniel A.; WONG, M. H. Franco. What drives companies to repurchase their stock? Available at: 〈http://www.chicagogsb.edu/capideas/oct04/repurchase.html > Accessed on March 6, 2007.

BEZERRA, Francisco Antonio; LOPES, Alexsandro Broedel. Lucro e preço das ações. In: IUDÍCIBUS, Sérgio de; LOPES, Alexsandro Broedel (Coord.) Teoria avançada da Contabilidade. São Paulo: Atlas, 2004.

BIRD, Ron; GERLACH, Richard; HALL, A. D. The prediction of earnings movements using accounting data: An update and extension of Ou and Penman. Journal of Asset Management, v. 2, n. 2, Sept. 2001.

BRASIL 1976. Lei $n^{\circ}$ 6.404 de 15 de dezembro de 1976. Available at < http://www.planalto.gov.br/CCIVIL/LEIS/L6404consol.htm> Accessed on Jan. 30, 2007.

BRASIL 1999. CVM Instruction no 299, de 9 de fevereiro de 1999. Available at: <http://www.cvm.gov.br/asp/cvmwww/atos/exiato.asp?Tipo=I\&File=/inst/inst010.htm $>$ Accessed on Aug. 15, 2006.

2000. Texto integral da CVM Instruction $n^{0}$ 299, de 9 de fevereiro de 1999, com as alterações introduzidas pela CVM Instruction $n^{\circ} \mathbf{3 4 5 / 0 0}$. Available at: $<$ http://www.cvm.gov.br/asp/cvmwww/atos/exiato.asp?Tipo=I\&File=/inst/inst010.htm $>$ Accessed on Aug. 15, 2006. 
2007. IPEADATA. Available at:

<http://www.ipeadata.gov.br/ipeaweb.dl/ipeadata?193821593 > Accessed on March 22, 2007.

BROWN, S; LO, K.; LYS, T. Use of $\mathrm{R}^{2}$ in accounting research: Measuring changes in value relevance over the last four decades. An empirical evaluation of accounting income numbers. Journal of Accounting and Economics, v. 28, n. 2, pp. 83-115, 1999.

COMMENT, R.; JARRELL, G. A. The relative signaling power of Dutch-auctions and fixed-price self-tender offers and open-market share repurchases. Journal of Finance, n. 46, pp. 1243-1271, 1991.

DANN, L. Y. Common stock repurchases - an analysis of returns to bondholders and stockholders. Journal of Financial Economics, n. 9, pp. 113-138, 1981.

DIELMAN, Terry; TIMOTHY J. Nantell; WRIGHT, Roger L. Price effects of stock repurchasing: A random coefficient regression approach. The Journal of Finance and Quantitative Analysis, v. 15, n. 1, pp. 175-189, March 1980.

DITTMAR, Amy K. Why do firms repurchase stock? The Journal of Business, v. 73, n. 3. July, pp. 331-355. 2000.

D`MELLO, R.M; SHROFF, Pervin K. Equity undervaluation and decisions related to repurchase tender offers: An empirical investigation. The Journal of Finance, v. 55, n. 5, pp. 2399-2424, Oct. 2000.

FAMA, Eugene F. FRENCH, Kenneth R. Multifactor explanations of asset pricing anomalies. Journal of Finance, v. 51, n. 1, March 1996.

GABRIELLI, Márcio F.; SAITO, Richard. Recompra de ações e proteção dos minoritários. Revista de Administração de empresas, v. 4 pp. 54-67, 2004.

GORDON, André. Recompra de ações: uma abordagem empírica. 2002. FGV Postgraduate program. Faculty adviser Dr. Marco Antonio Bonomo. Master's dissertation in economics. Available at $<$ www1.capes.gov.br/estudos/dados/2001/31011012/028/2001_028_31011012002P2_Te ses.pdf $>$.

GREENE, William H. Econometric Analysis. Rio de Janeiro: Prentice-Hall. 1997.

GRULLON, G.; MICHAELY, R. Dividends, share repurchases, and the substitution hypothesis. Journal of Finance, n. 57, 2002.

GUJARATI, Damodar. Basic Econometrics. 4th edition, McGraw-Hill, 2002.

HO, Li-Chin Jenifer; LIU, Chao-Shin; RAMANAN, Ramachandran. Open-market stock repurchase announcements and revaluation of prior accounting information. The Accounting Review, v. 72 n 3. July, pp. 475-487. 1997. 
IKENBERRY, David L.; LAKONISHOK, Josef; VERMAELEN, Theo. Stock repurchases in Canada: Performance and strategic trading. Journal of Finance, n. 55, pp. 2373-2397, 2000.

JENSEN, Michael C; MECKLING, William H. Theory of the firm: Managerial behavior, agency costs and ownership structure. Journal of Financial Economics, v. 3, n. 4, pp. 305-360, 1976.

LAKONISHOK, Josef; VERMAELEN, Theo. Anomalous price behavior around repurchase tender offers. The Journal of Finance, n. 45, pp. 455-477, June 1990.

LIANO, Kartono; HUANG, Gow-cheng; MANAKYAN, Herman. Market reaction to open market stock repurchases and industry affiliation. Journal of Business and Economics, n. 42, pp. 97-120, 1990.

LIE, Erik. Operating performance following open market share repurchase announcements. Journal of Accounting and Economics, n. 39, pp. 411-436, 2005.

LIMA, I.S; LIMA, G.A.S.F; PIMENTEL, R.(Coord.) Curso de mercado financeiro: tópicos especiais. São Paulo: Atlas, 2006.

LOPES, Alexsandro Broedel; GALDI, Fernando Caio. Financial Statement Analysis also Separate Winners from Losers in Brazil. São Paulo: FGV, 2006

Does financial statement analysis generate abnormal returns under extremely adverse conditions? In: Annual Meeting of the American Accounting Association. Chicago, Illinois. 2007.

MELLAGI FILHO, Armando; ISHIKAWA, Sérgio. Mercado financeiro e de capitais. São Paulo: Atlas. 2000.

MOREIRA, Luis Fernando. A Recompra de ações na BOVESPA. 2000. MBA dissertation. Postgraduate Program in Administration, UFRGS. Faculty adviser Dr. Jairo Laser Procianoy.

PIOTROSKI, Joseph D. Value investing: The use of historical financial statement information to separate winners from losers. Journal of Accounting Research, v. 38. pp. 1-41, 2000.

PROCIANOY, J.L; MOREIRA, Luiz Fernando. Open Market Stock Repurchases at São Paulo Stock Exchange - BOVESPA. In: Hervey Arbeláez, Reid William Click (Org). Latin American Financial Markets: Developments in Financial Innovations. 1st ed Oxford: Elsevier, 2004, v. 5, pp. 345-363.

ROSS, Stephen A.; WESTERFIELD, Jefrey F. J.; JAFFE, F.Administração financeira. 2nd ed. São Paulo: Atlas. 2002.

SANT'ANNA, Dimitri Pinheiro de. A Relevância das informações contábeis na Bovespa: avaliação dos modelos de residual income valuation e abnormal earnings growth. 2004. 149 f. Master's dissertation in accounting - Postgraduate Program in 
Accounting, Fundação Instituto Capixaba de Pesquisas em Contabilidade, Economia e Finanças (FUCAPE), Vitória, 2004.

SARLO NETO, Alfredo. SARLO NETO, Alfredo. A reação dos preços das ações à divulgação dos resultados contábeis: evidências empíricas sobre a capacidade informacional da contabilidade no mercado brasileiro. 2004. 243 f. Master's dissertation in accounting - Postgraduate Program in Accounting, Fundação Instituto Capixaba de Pesquisas em Contabilidade, Economia e Finanças (FUCAPE), Vitória, 2004.

SPENCE, A. M.. Job market signaling. Quarterly Journal of Economics. v. 87, n. 3, pp. 355-374, 1973.

STEPHENS, Clifford P.; WISBACH, Michael S. Actual share reaquisitions in openmarket repurchase programs. The Journal of Finance, v. 53 n. 1. Feb., pp. 313-333. 1998.

VERMAELEN, T. Common stock repurchases and market signaling. Journal of Financial Economics, n.9, pp.139-183, 1981.

WOOLDRIDGE, Jeffrey M. Introdução à econometria: uma abordagem moderna. São Paulo: Pioneira Thomson Learning, 2006.

\section{APPENDIXES}

APPENDIX A - Descriptive statistics of the variables used in Equations 4 to 6

\begin{tabular}{|c|c|c|c|c|c|c|c|c|}
\hline \multicolumn{2}{|l|}{ Variables } & \multirow{2}{*}{$\begin{array}{l}\text { Abnormal } \\
\text { return } t\end{array}$} & \multirow{2}{*}{$\begin{array}{l}\text { Debt/ Equity t } \\
1.74\end{array}$} & \multirow{2}{*}{$\begin{array}{l}\text { PTB t } \\
1.81\end{array}$} & \multirow{2}{*}{$\begin{array}{l}\text { Size t } \\
14.42\end{array}$} & \multirow{2}{*}{$\begin{array}{l}\text { Liquidity } \mathrm{t} \\
0.19\end{array}$} & \multirow{2}{*}{\begin{tabular}{|l} 
Debts/Assets t \\
0.54 \\
\end{tabular}} & \multirow{2}{*}{$\mathrm{N}$} \\
\hline \multirow{5}{*}{ General } & Mean & & & & & & & \\
\hline & Median & -0.13 & 1.13 & 0.81 & 14.37 & 0.01 & 0.52 & \multirow{4}{*}{1384} \\
\hline & $\begin{array}{l}\text { Standard } \\
\text { Deviation }\end{array}$ & 0.96 & 2.04 & 3.33 & 1.54 & 0.64 & 0.24 & \\
\hline & Minimum & -3.42 & 0.07 & 0.04 & 10.70 & 0.00 & 0.01 & \\
\hline & Maximum & 6.13 & 23.64 & 25.52 & 19.18 & 11.25 & 2.68 & \\
\hline \multirow{5}{*}{ Winners } & Mean & 0.00 & 2.44 & 2.16 & 15.11 & 0.37 & 0.57 & \multirow{5}{*}{62} \\
\hline & Median & 0.03 & 1.21 & 1.26 & 14.93 & 0.03 & 0.54 & \\
\hline & $\begin{array}{l}\text { Standard } \\
\text { Deviation }\end{array}$ & 0.75 & 3.94 & 3.92 & 1.59 & 1.07 & 0.21 & \\
\hline & Minimum & -2.95 & 0.25 & 0.08 & 11.34 & 0.00 & 0.19 & \\
\hline & Maximum & 1.65 & 23.64 & 23.50 & 18.82 & 7.67 & 1.08 & \\
\hline \multirow{5}{*}{ Losers } & Mean & 0.02 & 2.27 & 1.25 & 14.64 & 0.16 & 0.55 & \multirow{5}{*}{48} \\
\hline & Median & -0.07 & 1.17 & 0.96 & 14.68 & 0.01 & 0.49 & \\
\hline & $\begin{array}{l}\text { Standard } \\
\text { Deviation }\end{array}$ & 0.55 & 3.68 & 1.10 & 1.63 & 0.31 & 0.22 & \\
\hline & Minimum & -1.15 & 0.27 & 0.15 & 11.94 & 0.00 & 0.20 & \\
\hline & Maximum & 1.68 & 16.63 & 4.46 & 18.8 & 1.66 & 1.03 & \\
\hline
\end{tabular}


APPENDIX B - Pooled regression analysis by Equations 3 and 4

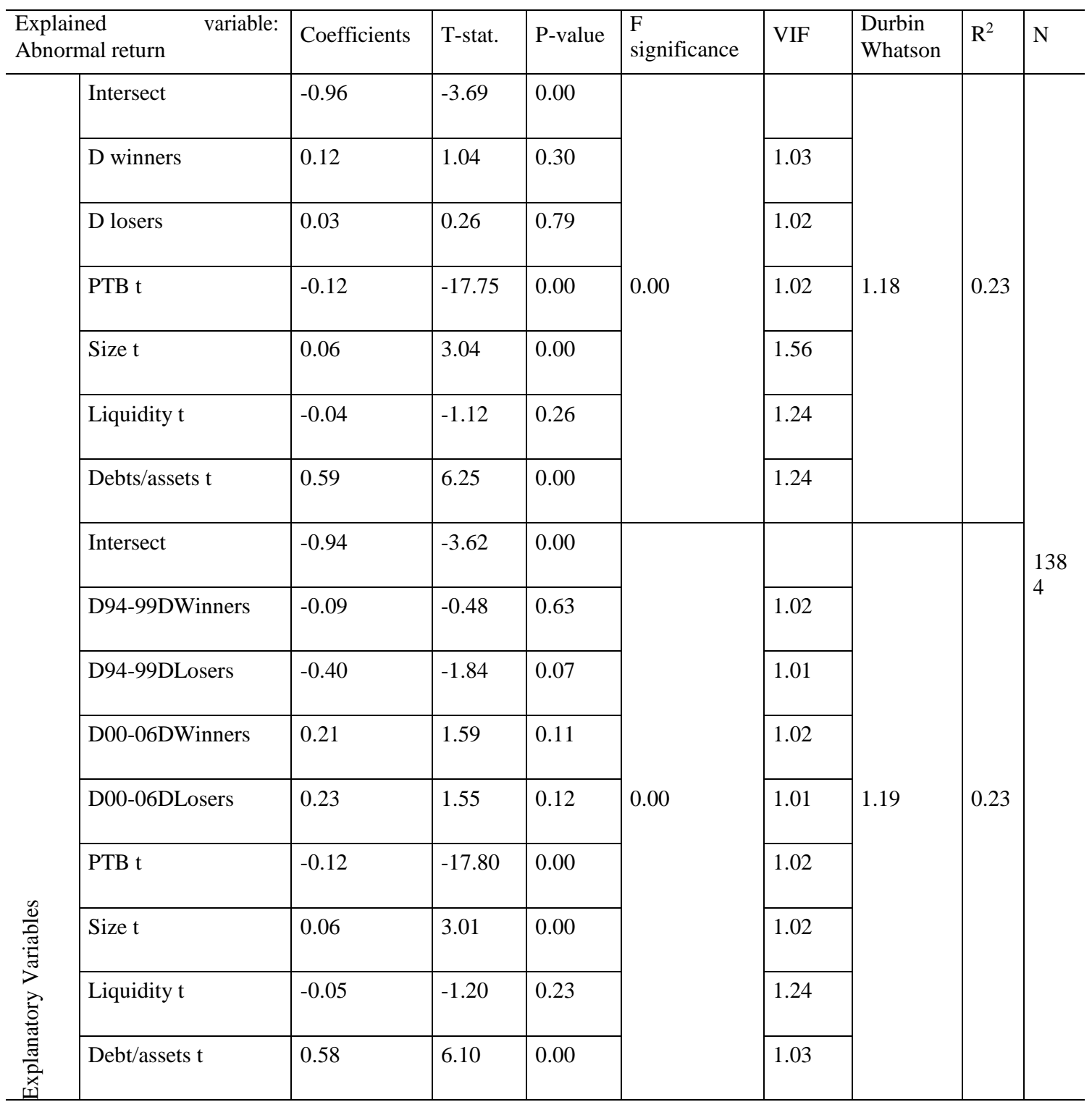

APPENDIX C - Panel regression analysis by Equations 5 and 6

$$
\begin{aligned}
& R A_{\text {it }}=\beta_{0}+\beta_{1} \delta_{\text {Winner }}{ }_{i t-2}+\beta_{2} \delta_{\text {Loser it }-2}+\beta_{3} \text { PTB it } \\
& +\beta_{4} \text { size it }+\beta_{5 . L i q}{ }_{i t}+\beta_{6} \text { Debt / equity it }+\xi_{i t}
\end{aligned}
$$

\begin{tabular}{l|l|l|l|l|l|l|l|l}
\hline$\beta_{0}$ & $\beta_{1}$ & $\beta_{2}$ & $\beta_{3}$ & $\beta_{4}$ & $\beta_{5}$ & $\beta_{6}$ & $F$ & Hausman \\
\hline-1.96 & 0.15 & -0.05 & -0.12 & 0.13 & 0.11 & 0.10 & \multirow{2}{*}{0.00} & 0.00 \\
\hline$(-1.46)$ & $(1.32)$ & $(-0.40)$ & $(-11.56)^{*}$ & $(1.38)$ & $(1.31)$ & $(4.01)^{*}$ & & \\
\hline
\end{tabular}




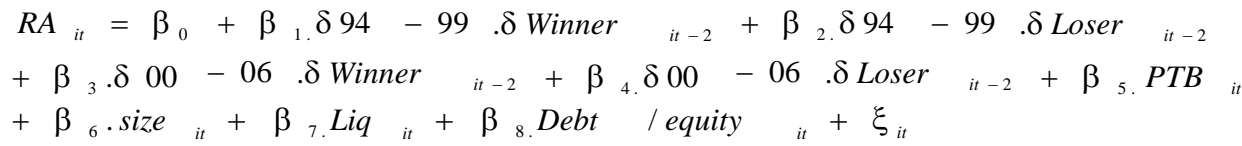

\begin{tabular}{l|l|l|l|l|l|l|l|l|l|l}
\hline$\beta_{0}$ & $\beta_{1}$ & $\beta_{2}$ & $\beta_{3}$ & $\beta_{4}$ & $\beta_{5}$ & $\beta_{6}$ & $\beta_{7}$ & $\beta_{8}$ & $F$ & Hausman \\
\hline-1.98 & 0.14 & -0.64 & 0.19 & 0.23 & -0.12 & 0.13 & 0.10 & 0.09 & \multirow{2}{*}{0.00} & \multirow{2}{*}{0.00} \\
\hline$(-1.49)$ & $(0.58)$ & $(-4.36)^{*}$ & $(1.65)$ & $(1.74)^{* * *}$ & $(-11.64)^{*}$ & $(1.41)$ & $(1.30)^{*}$ & $(3.83)^{*}$ & & \\
\hline
\end{tabular}

